Characterization of Fracture Patterns in the Geysers Geothermal Reservoir by Shear-wave Splitting

Final Report - 09/16/1996 - 09/15/1999

\author{
J. A. Rial \\ D. Erten
}

September 1999

Work Performed Under Contract No. DE-FG07-96ID13468

For

U.S. Department of Energy Assistant Secretary for Energy Efficiency and Renewable Energy Washington, DC

By

University of North Carolina Chapel Hill, NC 


\section{DISCLAIMER}

This report was prepared as an account of work sponsored by an agency of the United States Government. Neither the United States Government nor any agency thereof, nor any of their employees, make any warranty, express or implied, or assumes any legal liability or responsibility for the accuracy, completeness, or usefulness of any information, apparatus, product, or process disclosed, or represents that its use would not infringe privately owned rights. Reference herein to any specific commercial product, process, or service by trade name, trademark, manufacturer, or otherwise does not necessarily constitute or imply its endorsement, recommendation, or favoring by the United States Government or any agency thereof. The views and opinions of authors expressed herein do not necessarily state or reflect those of the United States Government or any agency thereof. 


\section{DISCLAIMER}

Portions of this document may be illegible in electronic image products. Images are produced from the best available original document. 


\title{
CHARACTERIZATION OF FRACTURE PATTERNS IN THE GEYSERS GEOTHERMAL RESERVOIR BY SHEAR-WAVE SPLITTING
}

\section{FINAL REPORT}

09/16/1996 - 09/15/1999

\author{
J. A. Rial \\ D. Erten
}

September 1999

Work Performed Under Contract No. DE-FG07-96ID13468

\author{
Prepared for the \\ U.S. Department of Energy \\ Assistant Secretary for \\ Energy Efficiency and Renewable Energy \\ Washington, DC
}

Prepared by

University of North Carolina

Chapel Hill, NC 


\title{
FINAL REPORT \\ Grant \# DE-FG07-96ID13468
}

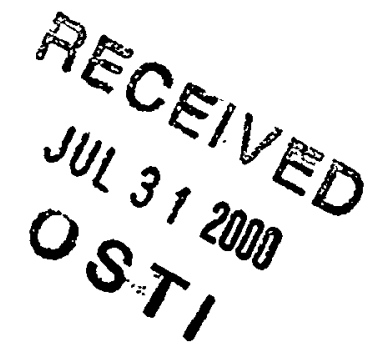

\section{Characterization of Fracture Patterns in The Geysers Geothermal Reservoir by Shear-wave Splitting}

\author{
Principal Investigator: J.A. Rial \\ Co-Principal Investigator: D. Erten \\ Wave Propagation Laboratory, Department of Geological Sciences, University of North Carolina at \\ Chapel Hill , NC 27599
}

\begin{abstract}
We have analyzed the splitting of shear waves from microearthquakes recorded by 16 station three-component seismic network at the Northwest Geysers geothermal field, Geysers, California, to determine the preferred orientation of subsurface fractures and cracks. Average polarization crack directions with standard deviation were computed for each station. Also, graphical fracture characterizations in the form of equal-area projections and rose diagrams were created to depict the results. The main crack orientations within the steam field are predominantly in the $\mathrm{N} 10^{\circ} \mathrm{E}$ to $\mathrm{N} 50^{\circ} \mathrm{E}$ direction, consistent with expected fracture directions in a pull-apart basin created by sub-parallel right-lateral strike-slip faults related to San Andreas fault system. Time delays range from 15-60 ms similar to the time delays from previous studies at geothermal reservoirs(Sato et al. 1991, Shalev and Lou 1995). We have detected a significant increase in time delays between 1988 and 1994, which we attribute to widening of the cracks or filling of the cracks with fluid. Increase in production activities during this time could have influenced this widening.
\end{abstract}

\section{Introduction}

Shear-wave splitting is commonly used to characterize the state of stress and fracture patterns in geothermal reservoirs. When shear waves propagate through an anisotropic media, their polarization is controlled by the media's anisotropy independent of the source. The incident wave is split into fast shear wave, parallel to the cracks, and slow shear wave, 
perpendicular to the cracks. After leaving the fractured interval, both shear waves propagate with the same velocity but have different polarizations and travel times, which were established by the fractured interval. The orientation of the fractures can be determined from the polarization of the first-arriving shear wave. Time delay between the fast and slow shear waves can be measured by cross-correlation on a seismogram.

The nature, distribution, and orientation of fractures in vapor-dominated geothermal fields such as The Geysers are of importance in the design of production strategies.

\section{Geological background}

The Geysers geothermal field is located northeast of the San Andreas fault in the northern Coast Range of California (110 km north of San Francisco). There is intense microseismicity in the field, some of which is induced by steam production.

Franciscan greywacke and intrusive rocks constitute the primary reservoir rocks at The Geysers. The reservoir rock is overlain by a variable but generally low-velocity complex assemblage of melanges, greenstones, serpentinites, graywackes, and metagraywackes (McLaughlin, 1981). The Late Jurassic to Late Cretaceous Franciscan rocks at The Geysers have been recently deformed by faulting and intruded by shallow magmas. Superimposed on the subduction-related thrust faults are strike-slip and normal faults. Two major rightlateral strike-slip faults related to San Andreas fault system, the Mercuryville and Collayomi fault zones, appear to form the southwest and northeast boundaries of the steam field, respectively (McLaughlin, 1981).

Locally, several northwest trending fault zones are evident, the most prominent being the Big Sulfur Creek fault zone which consists of near vertical and steeply dipping faults (Stockton et al., 1984). The Big Sulfur Creek fault zone merges with the northwest trending Squaw Creek fault zone in the northwestern part of the field.

There has been extensive seismic studies at the Geysers geothermal field in recent years. Conventional seismological studies were first carried out to obtain P- and S-wave velocities, $\mathrm{Vp} / \mathrm{Vs}$ ratios, seismic $\mathrm{Q}$ values within the Geothermal reservoir (e.g., Zucca et al. 1994, Romero et al, 1995, Julian et al, 1996). More recently, studies by our UNC-CH group (English and Rial, 1997, Erten and Rial, 1998) and at Duke University (Shalev and Malin, 1997) have focused in the determination of the crack directions using the shear-wave splitting method. 
In this paper we report on the latest determination of fracture patterns and time delays at the NW Geysers geothermal field by using the shear wave splitting method on the complete available seismographic data sets of local microseismicity.

\section{Methodology}

The shear-wave splitting method has been described extensively before (e.g. Crampin,1981; Lou and Rial, 1997; Lou et al.,1997). The effect is most clearly seen after the seismograms are rotated into the directions corresponding to the fast and slow shear-wave polarizations. To determine the fast shear-wave polarization the horizontal components of the seismograms are numerically rotated to search for the orientations along which the ratio of the projections of the particle displacement reaches a maximum (Shih and Meyer, 1989). In a time window that contains only the fast shear-wave arrival, the azimuth which this maximum ratio occurs at is taken as the polarization of the fast shear-wave. After appropriate rotation, the delay between the split shear-waves is measured by simple crosscorrelation (See Fig.1). Equal area projections (Fig. 2) and rose diagrams (Fig. 3) show the first motion directions obtained per station. These projections are an effective way determine the consistency of first motion polarization and to test the limits of the shear-wave window.

Since the recording instruments are down-hole, it is necessary to determine their true geographic orientations. To do this, we used measurements of the arrival angle of the Pwaves from near seismic events. Average of 30 near events per station were used to calculate a mean value with error less than $10^{\circ}$. The final geographic orientation of the cracks are obtained after correction for station orientation.

Although straightforward, the analysis of shear-wave splitting for the purpose of seismic imaging must be based on abundant sets of shear-wave seismograms. This is in part because the shear-wave splitting of small earthquakes is usually complicated by a number of factors: namely, the complexity of the source, the possible existence of several distinct crack directions along the path and the lithologic heterogeneity and local topography. A large number of measurements allows for an statistically robust determination of the preferred directions and the selection of the best possible data.

One major restriction to the shear-wave analysis is that the events need to be within a shear wave window underneath the receiver. This shear-wave window is defined by a critical angle $i_{c}=\sin ^{-1}(\beta / \alpha)$ where $\alpha$ and $\beta$ are the P-wave and S-wave velocities, respectively. For angles of incidence greater than $i_{c}$, shear-waves strongly interact with any free surface, thus obscuring the incoming waveform(Crampin and Booth, 1985). The critical angle is $35^{\circ}$ in a 
half-space with a Poisson's ratio of 0.25 . We have extended this angle to $45^{\circ}$ for the $\mathrm{NW}$ Geysers due to ray curvature caused by low-velocity layers.

\section{Shear-Wave Splitting From NW Geysers}

NW Geysers area is very active seismic zone with an average of 20 microearthquakes per day. Most of the earthquake activity is concentrated in the south eastern part of the Coldwater Creek Steam Field(CCSF) coinciding with the production area.

The data used for this study were recorded at the NW Geysers by a 16-station, digital, three component network operated by Lawrence Berkeley Laboratory during 1988 and part of 1994. All 16 stations had geophones about 30 meters below the surface, the signals which were sampled at $400 \mathrm{~Hz}$. For this study over 30,000 seismograms were processed and analyzed. This allowed the selection of about 40 "ideal" events per station, those that showed large signal-to-noise ratio, and clear, robust shear-wave arrivals, as well as arrival angle within the shear-wave window. Those events that were below $10 \mathrm{~km}$ were not analyzed.

In the NW Geysers area the cracks were assumed to be vertical, a relatively safe assumption, since most hydraulic fracture operations appear to confirm it. A second assumption is that the fracture systems are uniformly aligned, so that the observed fast and slow polarization directions do indeed reflect the local fracture orientations.

\section{Fracture Orientations}

Figure 3 shows the rose diagrams of the corrected polarization directions of leading shear wave for the 16-station network. It is clear from this rose diagram that most of the crack orientations are uniformly aligned, and show the presence of a dominant direction. Comparison of the results obtained from data recorded in 1994 and 1998 indicate that there has not been a significant change in the polarization directions with time.

Main crack directions: The main crack orientations within the steam field are predominantly in the $\mathrm{N} 10^{\circ} \mathrm{E}$ to $\mathrm{N} 50^{\circ} \mathrm{E}$ (for stations $1,2,3,4,5,6,7,8,10,11$ ) direction with the exception of crack orientation around station 9 which is parallel to the strike of a local fault striking $\mathrm{N} 50^{\circ} \mathrm{W}$. Since most of the earthquake activity is concentrated in the southeastern area of the reservoir, data for rays arriving within the shear-wave window outside of the steamfield is limited. Approximately, outside of the steam field crack orientations are $\mathrm{N} 35^{\circ} \mathrm{E}$ $\mathrm{N} 60^{\circ} \mathrm{E}$ (for stations $12,13,15$ ), $\mathrm{N} 25^{\circ} \mathrm{W}$ (for stations 14), $\mathrm{N}$-S(for station 16). Detailed projections of the polarizations of the leading shear wave arrivals in equal-area projections for selected-stations are shown in Figure 2. Data are for measurements of polarization within 45 degrees from the vertical beneath each station (the inner circle in the diagram). 
Time Delays: Time delay between the fast and slow shear wave is measured on a seismogram by simple cross-correlation. In a window containing only the shear-waves, this interval is measured from the beginning of arrival of the fast shear-wave to the onset of the slow shear-wave. This method of obtaining the time delays contains uncertainties involved in picking shear-wave arrival times. Therefore, particle motion diagrams are used to aid in identifying the arrival of the slower shear-wave. When there is an abrupt change in direction from the initial linear polarization, this is indicative of arrival of the delayed shear wave(See Fig.1). After processing large number of seismograms we determined that the time delays range from 15 to $40 \mathrm{~ms}$. for 1988 data and 20 to $60 \mathrm{~ms}$ for 1994 data. Figure 4 shows the distribution of delay times for selected stations for each year of data. Figure 5 shows plot of delay times vs. hypocentral distance to each MEQ event for corresponding data for selected stations at the NW Geysers. It is clear that there has been a significant increase in delay times between 1988 and 1994 where at some stations increase of as much as twice the value of 1988 delay times.

\section{Discussion}

The result of our studies at the NW Geysers have shown that the leading polarization direction of shear-waves is dominantly in direction of $\mathrm{N} 10^{\circ} \mathrm{E}$ to $\mathrm{N} 50^{\circ} \mathrm{E}$ (see Figure 1). This crack alignment is consistent with a local structure characterized by a pull-apart block structure limited by two right-lateral strike-slip faults oriented NW-SE.

The crack patterns we have detected are fully consistent with the existence of aligned fractures held open by a regional northeast-southwest maximum horizontal compressive stress in the Northwest Geysers (Romero, 1995). The results are also consistent with studies by Nielson et al. (1991) who measured fracture orientations in cores inside the $\mathrm{CCSF}$ and found predominant north-northeast strikes of fractures parallel to the maximum horizontal compressive stress.

The observed range of time delays at NW Geysers is also consistent with previous shear-wave studies at other geothermal reservoirs (Sato et al. 1991, Shalev and Lou 1995). Particle motion diagrams reveal that at the $30 \mathrm{~m}$. deep receivers the synthesized particle motions are strongly linear and their polarization do not seem to be affected by the reflected waves.

Non-uniformly aligned fractures either beneath the station or along significant fractions of the source-receiver path may account for variable strike directions at stations $\mathrm{S} 5, \mathrm{~S} 10$ and S12. It is possible that near these stations the fracture systems are not vertical, 
producing a complicated mix of fast and slow waves. We are currently developing models to study changes in shear-wave polarizations with depth.

We have detected a significant increase in time delays between 1988 and 1994, which could be attributed to production and/or injection activities that have caused either mineralization or widening of cracks.

\section{Acknowledgments}

This research is supported by the Idaho National Engineering Laboratory(INEL) of the US Department of Energy under Contract No. DE-FG07-961D13468. Special thanks to Drs. Ernest Majer and Arturo Romero at Lawrence Berkeley Laboratory (LBL) for making the down-hole microearthquake data at the NW Geysers available to us.

\section{REFERENCES}

Crampin, S. and D.C., Booth, Shear-wave polarization near the North Anatolia Faults. II. Interpretation in terms of crack-induced anisotropy. Geophys. J. Roy. Soc, 83, 75-92, 1985.

Crampin, S., A review of wave motion in anisotropic and cracked elastic-media, Wave Motion, 3, 343-391, 1981.

Julian, B. R., A. Ross, G.R. Foulger, and J.R. Evans, Three-dimensional seismic image of a geothermal reservoir: The Geysers, California, Geophy. Res. Let., 23, 685-688, 1996

Lou, M. and J.A. Rial (1997): Characterization of geothermal reservoir crack patterns using shear-wave splitting, Geophysics, v 62, (2), p487-495.

Lou, M., E. Shalev and P.E. Malin, Shear-wave splitting and fracture alignments at the Northwest Geysers, California, Geophys. Res. Let., Vol.24, No.15, 1895-1898, 1997.

Majer, E. L. and T. V. McEvilly, Seismological investigations of the Geysers geothermal field, Geophysics, 44, 246-269, 1979.

McLaughlin, J.R., Tectonic setting of pre-Tertiary rocks and its relation to geothermal resources in The Geysers-Clear Lake area. USGS Professional paper 1141, 3-23, 1981

Nielson, Dennis L. et al., Fracturing in the Northwest Geysers, Sonoma County, California, Geothermal Resources Council Trans., Vol.15, October 1991 
Romero, A. E., T. V. McEvilly, E. L. Majer, and D. Vasco, Characterization of the geothermal system beneath the Northwest Geysers steam field, California, from seismicity and velocity patterns, Geothermics, 23, 111-126, 1995.

Sato, M., N. Matsumoto, and H. Niitsuma, Evaluation of geothermal reservoir cracks by shear-wave splitting of acoustic emission: Geothermics, 20, 197-206, 1991

Shalev, E., and M. Lou, A preliminary tomographic inversion of crack density in the Coso geothermal field: EOS (Transactions), 76, No.46, 351, 1995

Shih, X.R., P. Meyer, P. and J.F. Schneider, An automated, analytical method to determine shear-wave splitting. Tectonophysics, 165, 271-278, 1989.

Zucca, J.J., L. J. Hutchings, and P. W. Kasameyer, Seismic velocity and attenuation structure of the Geysers geothermal field, California, Geothermics, 23, 111-126, 1994. 


\section{NW Geysers Event 8803052102p}

\section{Rotation 152.0 from East}
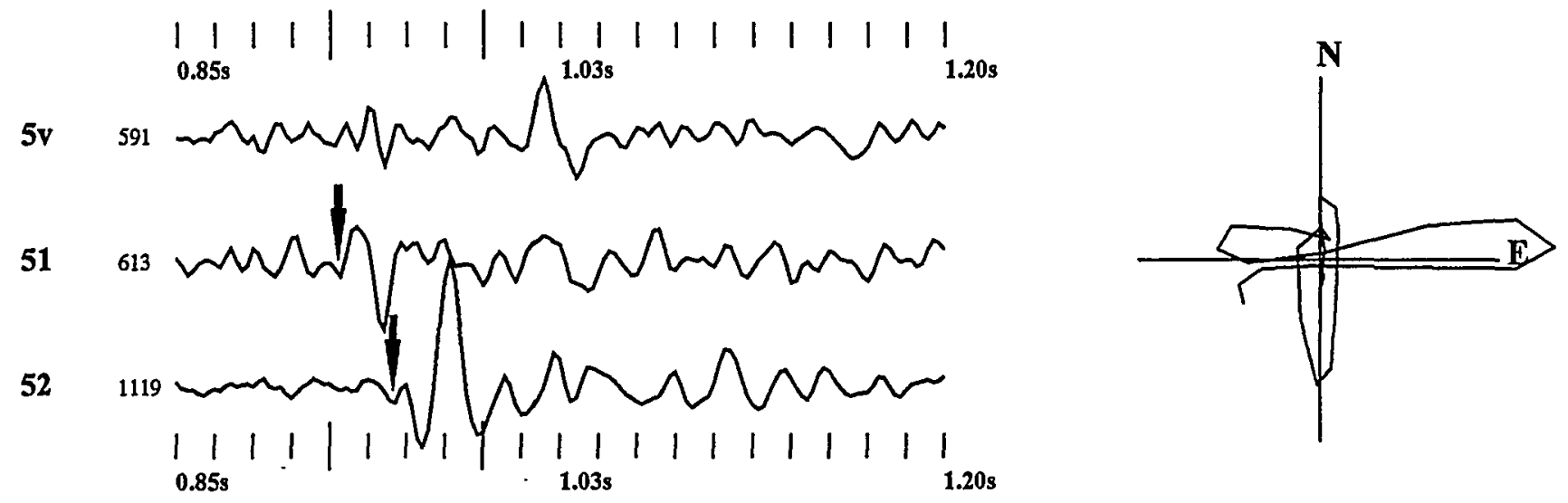

NW Geysers Event 8802061218p

Rotation 25.0 from East
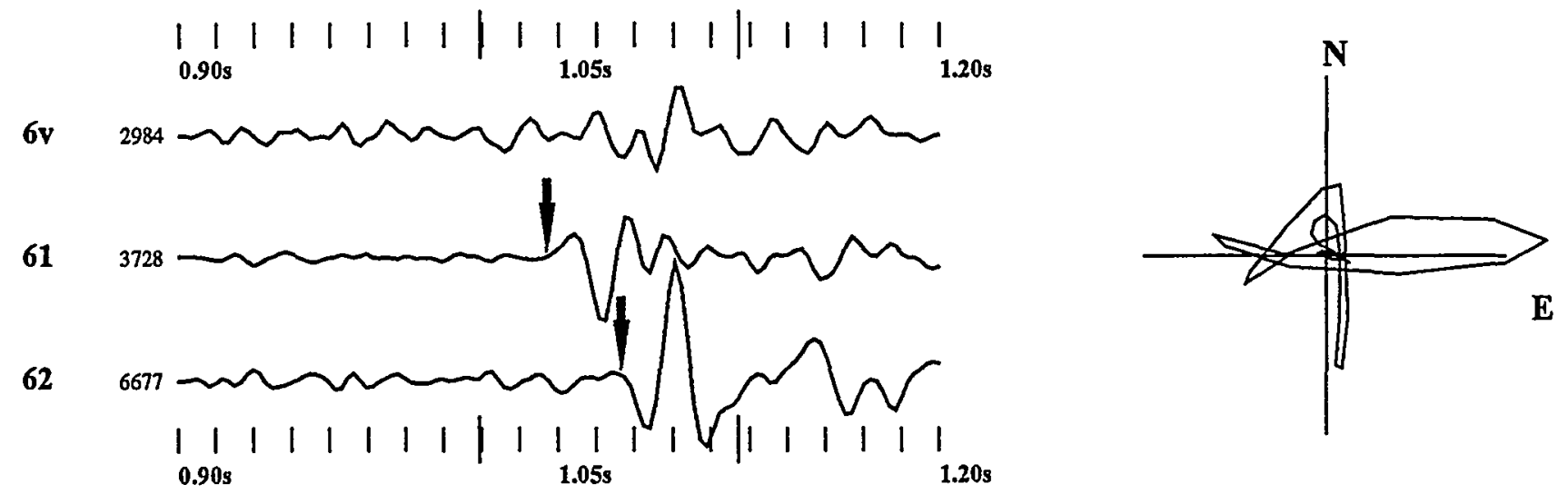

Figure 1: Seismograms illustrating the split between the fast and the slow shear-waves for selected Geysers events 


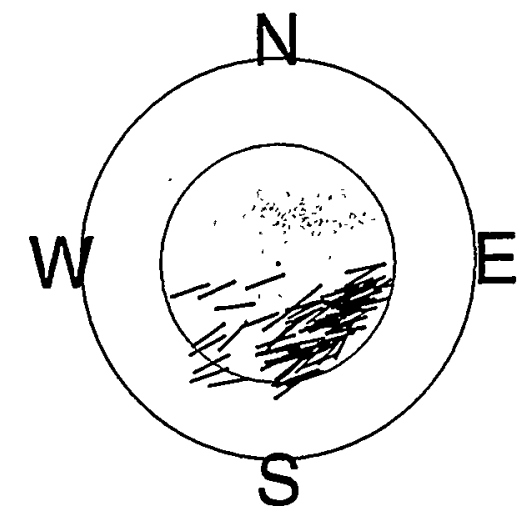

Station S3

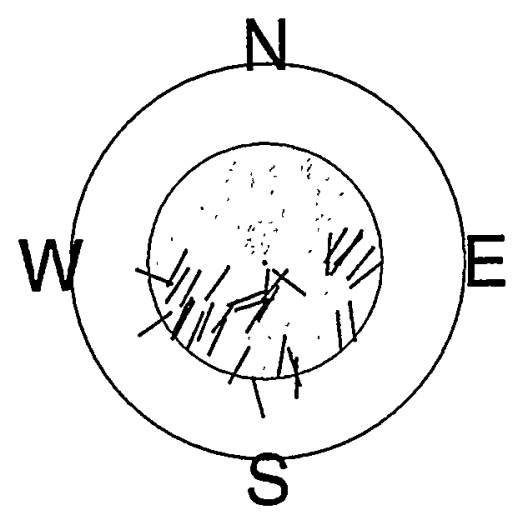

Station $\mathrm{S7}$

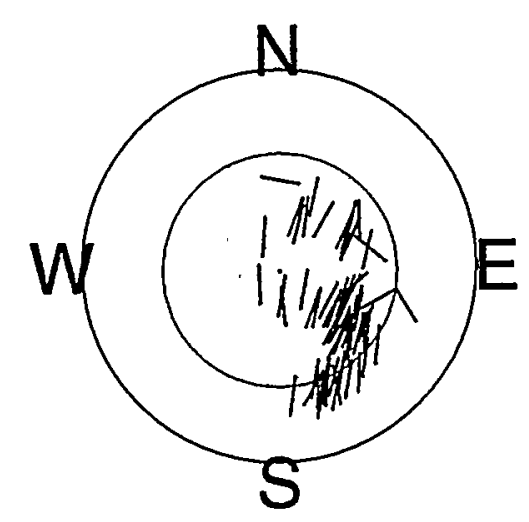

Station S11

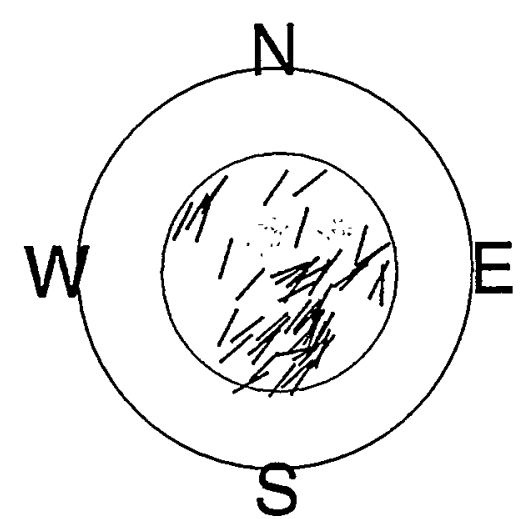

Station S4

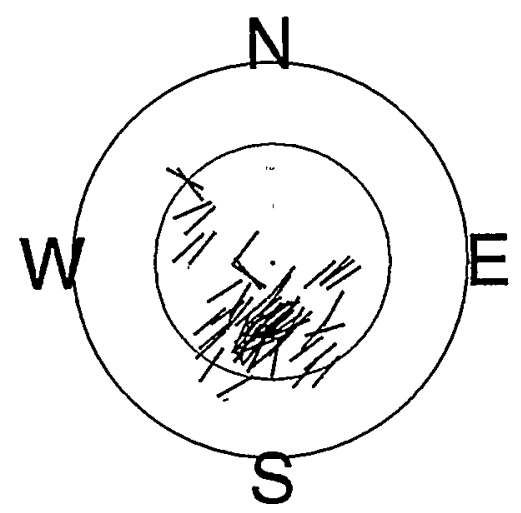

Station S8

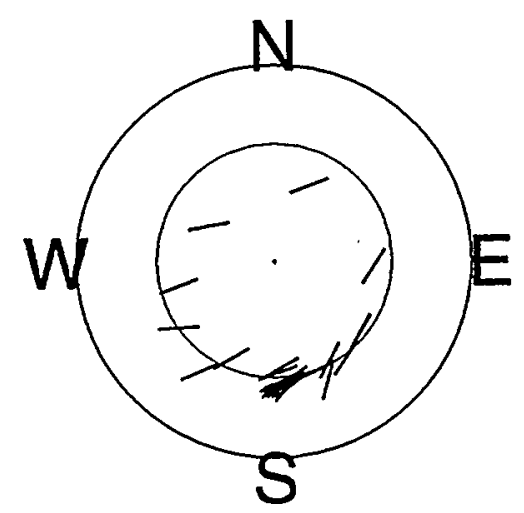

Station S15

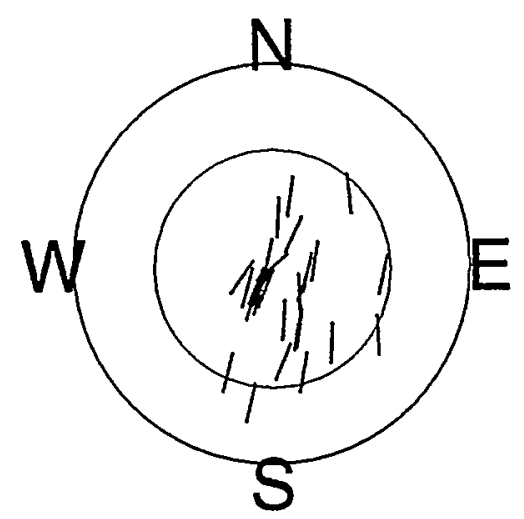

Station S5

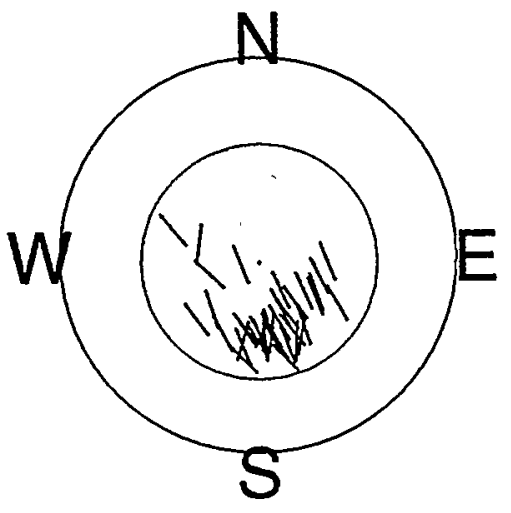

Station S9

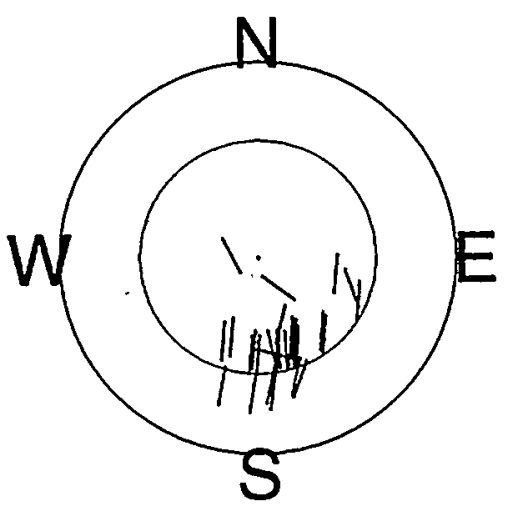

Station S16

Figure 2 : Equal Area Projections of the fast shear-wave for selected stations at NW-Geysers 


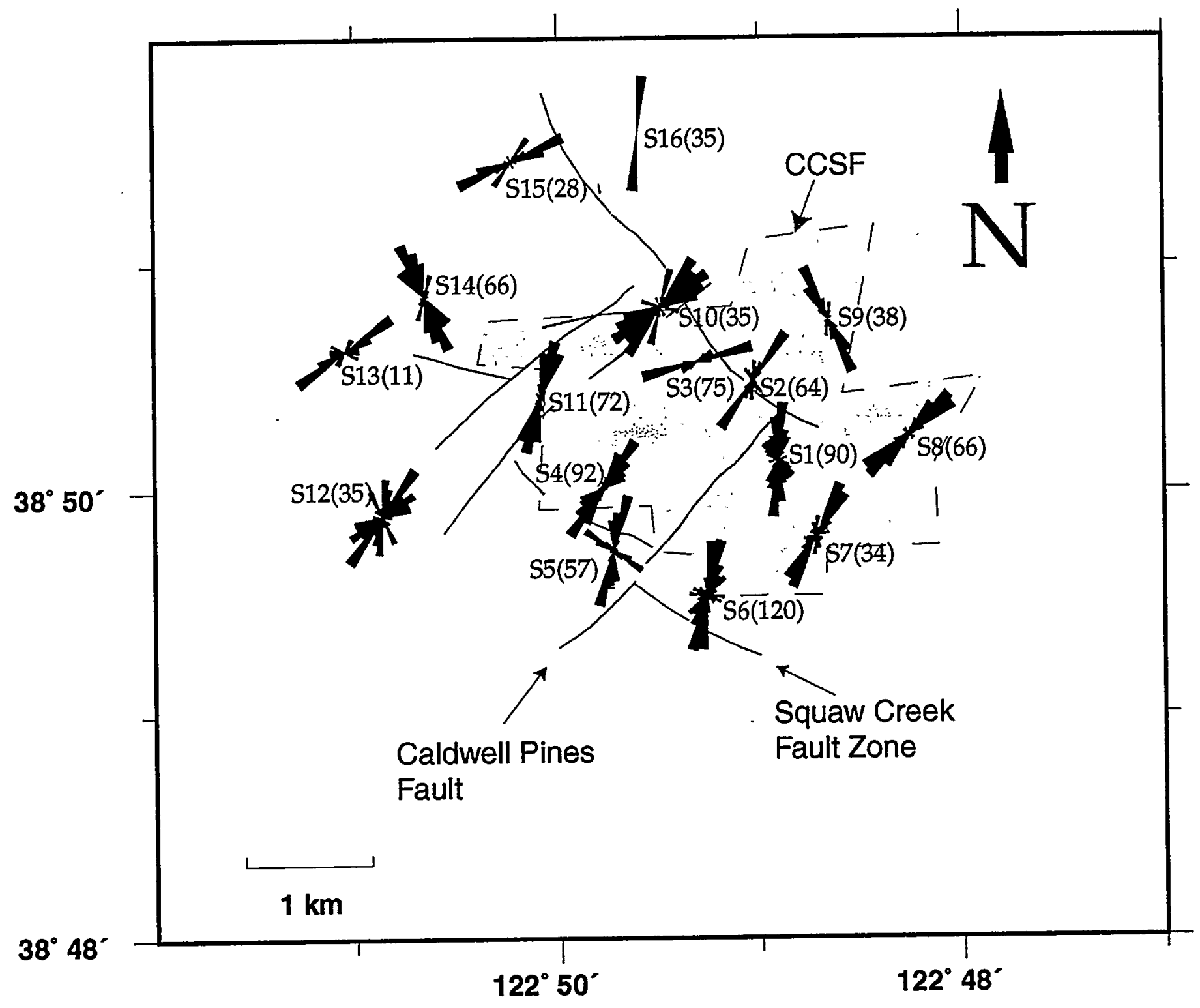

Figure 3: Polarization Directions of Fast S-Waves in NW Geysers (Number of events used for each station is in parantheses) 


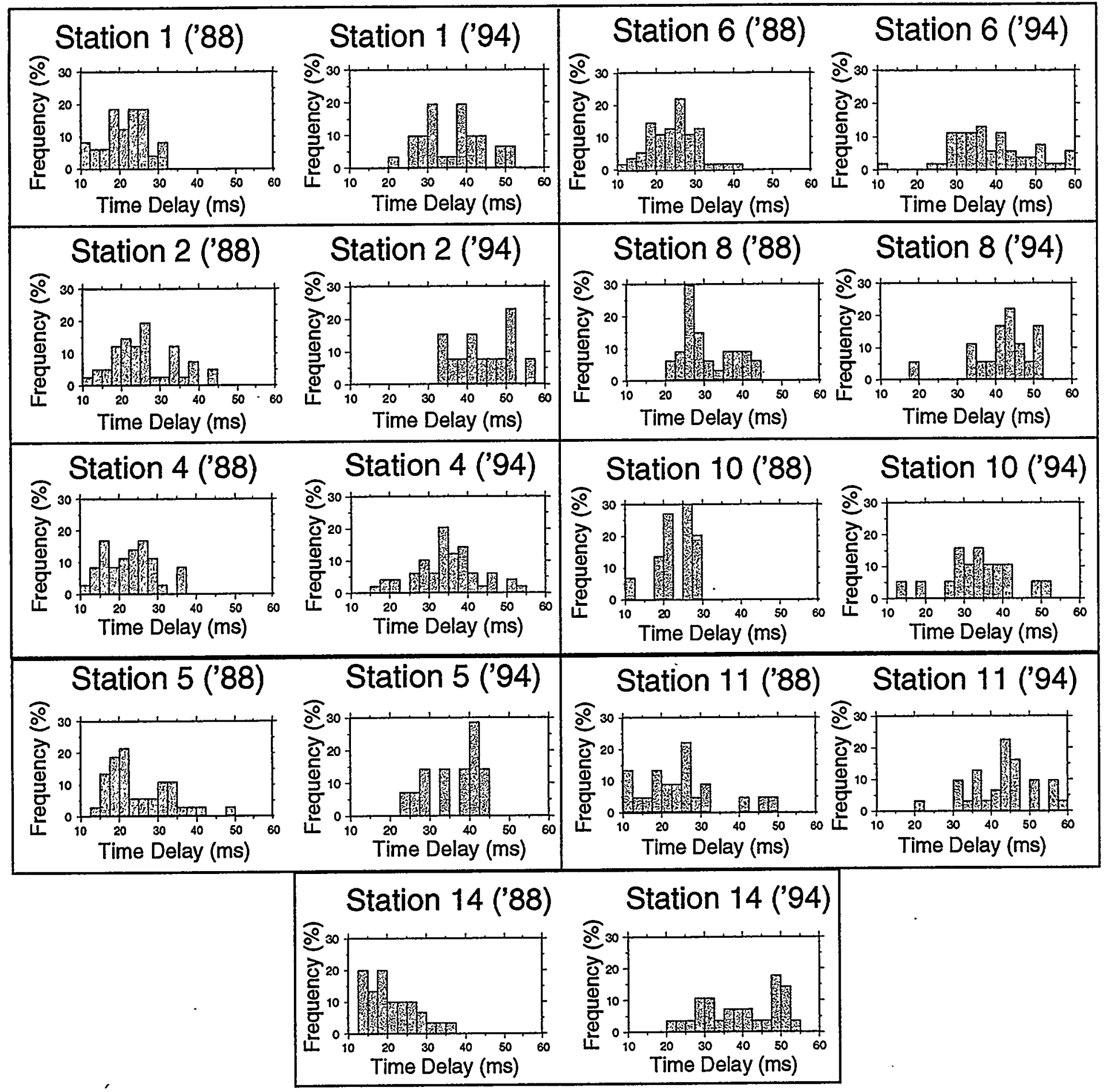

Figure 4: Time Delay vs. Number of Events Distribution for selected stations at NW Geysers.

Note: Stations 3,7,9 inoperative through '94

Stations 12, 13, 15, 16 - insufficient data for '94 


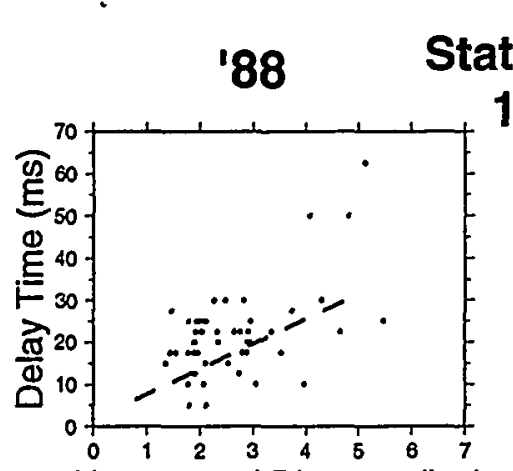

Hypocentral Distance $(\mathrm{km})$

'88

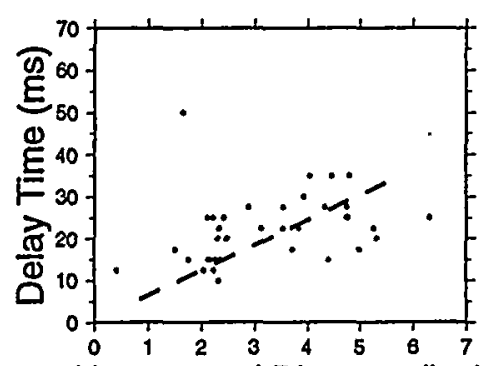

Hypocentral Distance (km)

Station

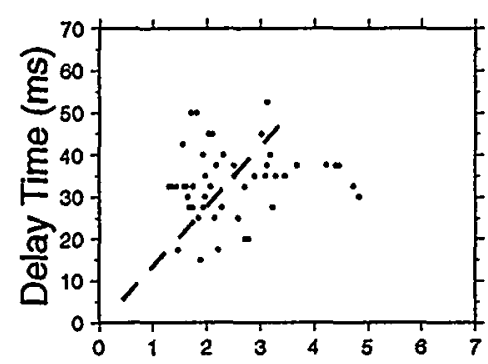

Hypocentral Distance (km)

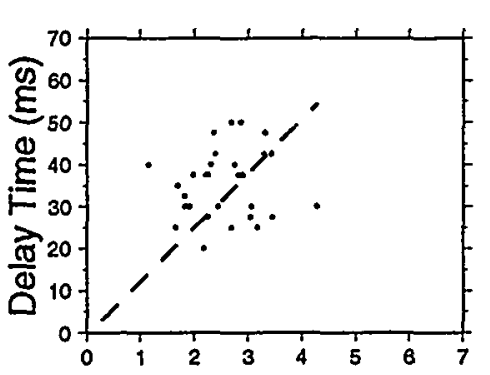

Hypocentral Distance $(\mathrm{km})$

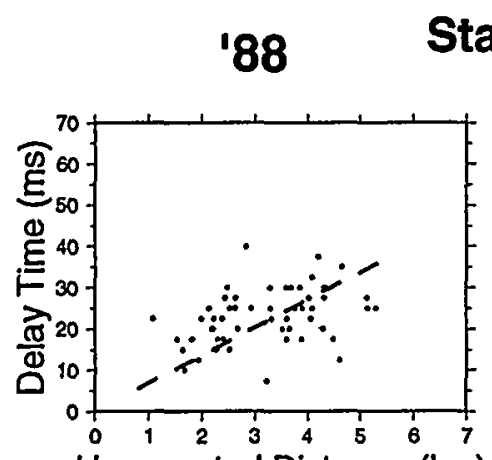

Hypocentral Distance $(\mathrm{km})$

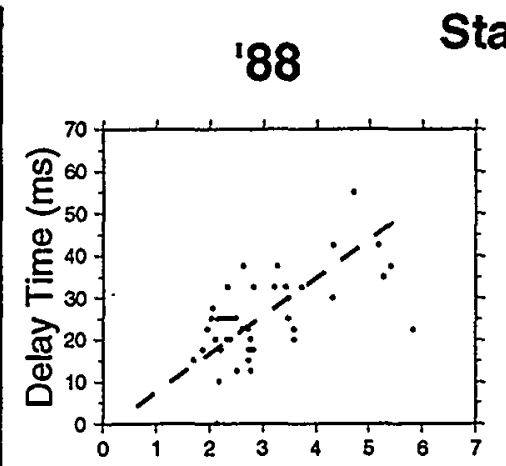

Hypocentral Distance (km)
2

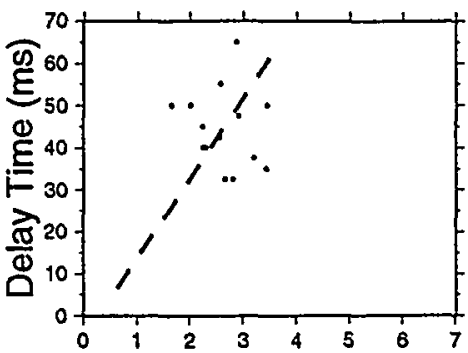

Hypocentral Distance $(\mathrm{km})$
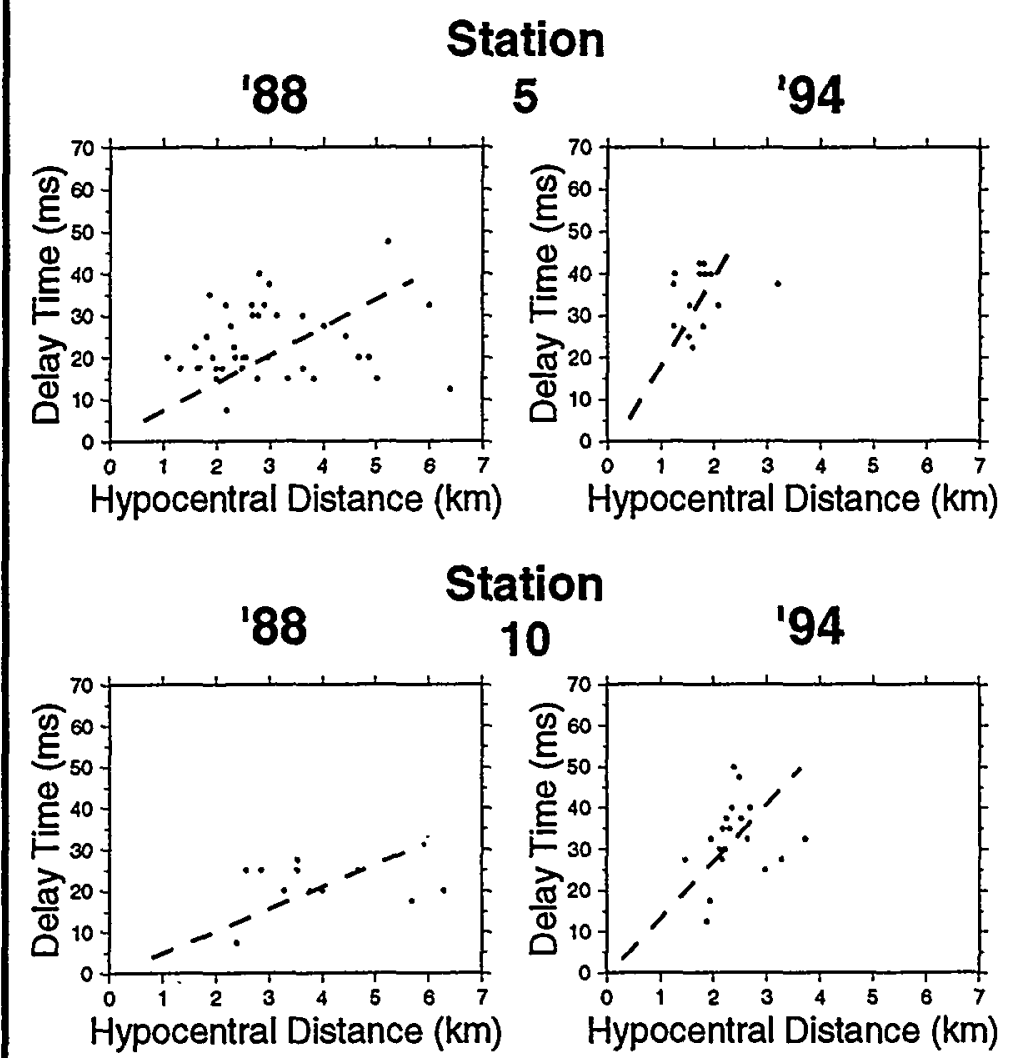

Hypocentral Distance $(\mathrm{km})$

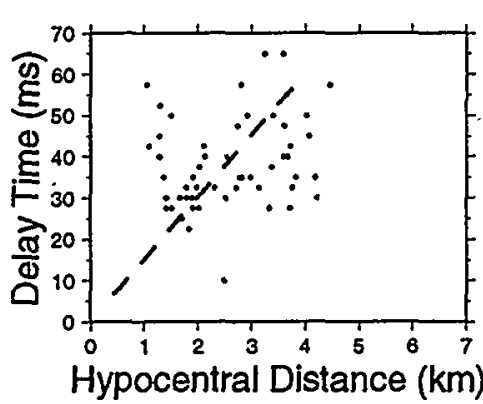

Station

188

11

'94

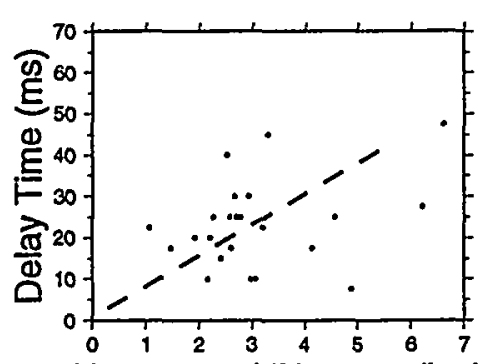

Hypocentral Distance (km)

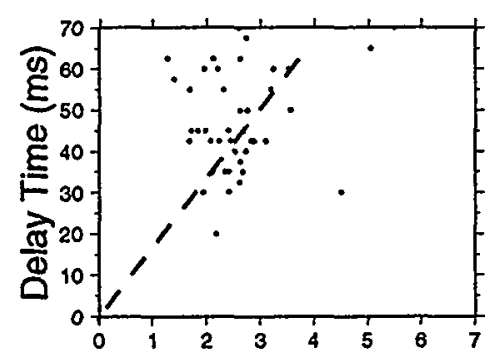

Hypocentral Distance (km)

\section{Station}
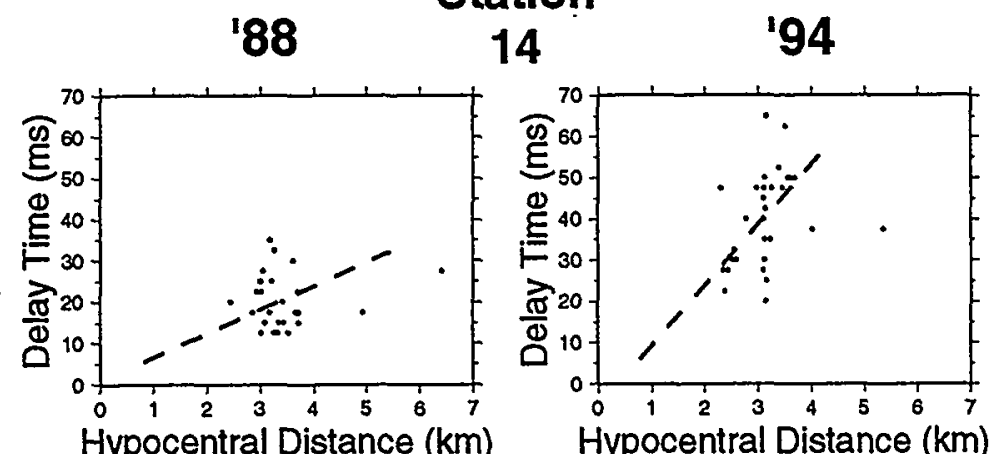

Hypocentral Distance $(\mathrm{km})$

Figure 5: Time Delay vs. Hypocentral Distance for selected stations at NW Geysers.

Note: Stations 3,7,9 inoperative through '94

Stations 12, 13, 15, 16 - insufficient data for '94 